\title{
Use of Labeled Primers for Differential Display
}

Tatjana Paunesku and Gayle E. Woloschak

Center for Mechanistic Biology and Biotechnology

Argonne National Laboratory

9700 South Cass Avenue

Argonne, IL 60439-4833

"To whom correspondence should be addressed

$$
\begin{aligned}
& \text { The submitted manuscript has been authored } \\
& \text { by a contractor of the U.S. Government } \\
& \text { under contract No. W-31-109-ENG-38. } \\
& \text { Accordingly. the U. S. Government retains a } \\
& \text { nonexclusive. royalty-free license to publish } \\
& \text { or reproduce the published form of this } \\
& \text { contribution, or allow others to do so. for } \\
& U \text {. S. Government purposes. }
\end{aligned}
$$




\section{DISCLAIMER}

This report was prepared as an account of work sponsored by an agency of the United States Government. Neither the United States Government nor any agency thereof, nor any of their employees, make any warranty, express or implied, or assumes any legal liability or responsibility for the accuracy, completeness, or usefulness of any information, apparatus, product, or process disclosed, or represents that its use would not infringe privately owned rights. Reference herein to any specific commercial product, process, or service by trade name, trademark, manufacturer, or otherwise does not necessarily constitute or imply its endorsement, recommendation, or favoring by the United States Government or any agency thereof. The views and opinions of authors expressed herein do not necessarily state or reflect those of the United States Government or any agency thereof. 


\section{DISCLAIMER}

Portions of this document may be illegible in electronic image products. Images are produced from the best available original document. 


\section{ABSTRACT}

The differential display of eukaryotic cDNAs using PCR allows for determination of mRNA species differentially expressed when comparing two similar cell populations. This procedure uses a $\left(T_{12} \mathrm{XY}\right.$ oligonucleotide as the $3^{\prime}$ primer and an arbitrary 8-10-mer as the $5^{\prime}$ primer. Labeling occurs by inclusion of $\alpha\left[^{33} \mathrm{P}\right]-d A T P$ in the $\mathrm{PCR}$ reaction. Two artifacts caused by this approach are (1) random priming from dT present from affinity purification of PolyA+ RNA and (2) hybridization of the arbitrary primer to template target sequences on both cDNA strands. In this work, we have developed an approach for both eliminating smearing and identifying nonspecific bands on sequencing gels. By separately using $5^{\prime}$-end-labeled $\left(T_{12} \mathrm{XY}\right.$ and arbitrary primers to label bands and comparing two differential display patterns rather than including labeled nucleotides in the PCR reaction itself, we can detect only those products incorporating the $(\mathrm{T})_{12} \mathrm{XY}$ primer on the $3^{\prime}$ ends and the arbitrary primer on $5^{\prime}$ ends. Those bands that are generated randomly in the PCR reaction are readily detectable and can be ignored. If, on the other hand, one is interested only in a diagnostic banding pattern for differential display, benefit can be derived from the simplicity of the pattern obtained when labeled $\left(\mathrm{T}_{12}\right) \mathrm{XY}$ is used. 


\section{INTRODUCTION}

Differential display of eukaryotic mRNA by means of PCR is a technique developed by Liang and Pardee (1-3) with the purpose to separate and, eventually, to clone individual messenger RNAs differentially expressed in mRNA preparations from similar but not identical cells. Briefly, transcripts from different cell populations are extracted, reverse transcribed in the presence of $(\mathrm{T})_{12} \mathrm{XY}$ as a primer, and the cDNA products with appropriate primer-hybridizing sequences are amplified in a labeled PCR reaction. The resulting short sequences are displayed on conventional sequencing gels. The pair of primers used for the PCR reaction are an arbitrary 8-10 mer as the $5^{\prime}$ primer and $(T)_{11} \mathrm{XY}$ or $(T)_{12} \mathrm{XY}$ as the $3^{\prime}$ primer. Reaction conditions are such that $5^{\prime}$ primers - regardless of their length - actually behave like 6- or 7mers for the first few rounds of amplification $(1,3,4)$. This degeneracy permits hybridization of $5^{\prime}$ primer to a wide range of transcripts expressed in the cell types of interest. It is advised that a primer be checked for the ability to produce 50-100 fragments of different lengths evident on a sequencing gel. Anchoring the $3^{\prime}$ primer at $5^{\prime}$ end of the polyA tail of mRNA enables exclusive screening of processed mRNAs and is therefore important for this approach especially if total RNA is to be used as template. However, previous work does not determine an approach to ensure that the products evident on the gel are primed by $(\mathrm{T})_{12} \mathrm{XY}$ and not by the arbitrary primer alone. One of the possible 
difficulties discussed in the initial method is that polyT that flows through the dT columns unavoidably primes PCR reactions from many positions along long. polyA tails of mRNAs, thus competing with the $\left(\mathrm{T}_{11} \mathrm{XY}\right.$ or $(\mathrm{T})_{12} \mathrm{XY} 3^{\prime}$ primer (2). Therefore, any single mRNA molecule tends to produce a smear evident of sequencing gel, with the smear being made up of bands varying in size for up to $200 \mathrm{bp}$ or longer as a function of length of the polyA tail. The authors suggest few possible solutions for this problem: a) using a small initial amount of polyA mRNA, or b) using total cellular RNA that was never purified by oligo dT column chromatography (2). An additional confounding issue has not been addressed: the intrinsic ability of any single oligomer to serve as both $5^{\prime}$ and $3^{\prime}$ primers in PCR amplification, an approach which has been used in many other applications of PCR technology such as genomic fingerprinting $(5,6)$ or total RNA fingerprinting (7). Comparisons of the theoretical expectation of the number of displayed mRNAs with the experimental data, for a given length of arbitrary primer have been made $(1,4)$; and higher than expected experimental number of bands was explained as a result of degenerate hybridization of primer and target under specified PCR conditions $(1,4)$. Using the same assumption, one may expect that the same degenerate primer hybridization may occur at many sites on both strands of the cDNA molecules resulting in formation of artifactual bands. This problem may become very significant in the case of using total RNA as a template because of the significant increase in the complexity of target. 
In this paper, we propose a slightly different approach that at the same time makes one able to ignore poly $\mathrm{T}$ contamination and ensures that contamination with products of random priming by $5^{\prime}$ primers will be detected as such on the sequencing gel.

\section{MATERIALS AND METHODS}

\section{Mice}

The availability of mice bearing the $w s t / w s t$ trait in the laboratory provided us with a ready source of tissues. The $w s t / w s t$ mice were bred in the sterile, hooded animal facility in the Center for Mechanistic Biology and Biotechnology at Argonne National Laboratory from $w s t /+$ breeding pairs obtained from the Jackson Laboratory (Bar Harbor, ME). Because the wasted trait is inherited as an autosomal recessive disorder, approximately $25 \%$ of the animals in each litter can be diagnosed (by neurologic examination) as having the syndrome $(8,9)$. The remainder of the litter appears normal. Normal littermates of $w s t / w s t$ mice are labeled $w s t / \cdot$. These $w s t / \cdot$ mice should be a mixture of $67 \%$ $w s t /+$ and $33 \%+/+;$ they serve as age-matched controls. Age-matched $\mathrm{BCF}_{1}$ $\left[(\mathrm{BALB} / \mathrm{c} \times \mathrm{C} 57 \mathrm{Bl} / 6) \mathrm{F}_{1}\right]$ mice also served as controls. For each experiment, thymuses from 3-5 animals (mixed male and female) were pooled, or, in the case of liver, 1-3 tissues were pooled. 


\section{mRNA Preparation}

Frozen thymus tissues were thawed in homogenization buffer $(0.075 \mathrm{~mol} / \mathrm{L}$ sodium chloride, $0.025 \mathrm{~mol} / \mathrm{L}$ disodium EDTA, $0.02 \mathrm{~mol} / \mathrm{L}$ Tris, $\mathrm{pH} 8.0$, and $0.5 \mathrm{~g} / \mathrm{L}$ sodium dodecyl sulfate) and homogenized in a Waring blender with an equal volume of fresh phenol. Following phenol extraction, samples were precipitated from ethanol overnight at $-20^{\circ} \mathrm{C}$. The pellet was dissolved in water and RNA was precipitated from $3 \mathrm{~mol} / \mathrm{L}$ sodium acetate ( $\mathrm{pH}$ 6.0) for 2 hours at $4^{\circ} \mathrm{C}$. Poly A+ RNA was separated from total RNA using oligodeoxythymidylate affinity column chromatography (Pharmacia oligo dT column was used). mRNA was quantitated by monitoring absorbance at $260 \mathrm{~nm}(10,11)$. Liver mRNAs were isolated according to the procedure of Lai et al. (12).

\section{Primers}

The following primers were used for all experiments reported here: two $3^{\prime}$ primers: $(\mathrm{T})_{12} \mathrm{MA}$ :TTTTTTTTTTMA and $\left(\mathrm{T}_{12} \mathrm{MC}\right.$ :TTTTTTTTTTTMC; and three 5' primers: R1:TCCTGTGACC; Ltk 3:CTTGATTGCC and S5:CCCAAGATTGAAGATGAGGA.

\section{Reverse Transcription and PCR Reactions}

RNA template was mixed with $20 \mathrm{pM}$ of $(\mathrm{T})_{12} \mathrm{XY}$ primer in a total volume of 19 $\mu l$ of $1 \times$ reaction buffer $(50 \mathrm{mM}$ Tris $\mathrm{HCl} \mathrm{pH} 8.3,75 \mathrm{mM} \mathrm{KCl}$ and $3 \mathrm{mM}$ 
$\left.\mathrm{MgCl}_{2}\right), 20 \mu \mathrm{M}$ dNTP, $10 \mathrm{mM}$ DTT; and incubated $5 \mathrm{~min}$ at $65^{\circ} \mathrm{C}$ and then 10 $\min$ at $37^{\circ} \mathrm{C}$. M-MLV reverse transcriptase (GIBCO-BRL) was added (200 units per sample) and mix incubated for $50 \mathrm{~min}$ at $37^{\circ} \mathrm{C}$. Enzyme inactivation incubation was $5 \mathrm{~min}$ at $95^{\circ} \mathrm{C}(1-4)$.

\section{PCR with $\alpha\left[{ }^{33}\right.$ P]dATP incorporation}

For a single reaction $8 \mathrm{pM}$ of each primer $(\mathrm{T})_{12} \mathrm{XY}$ and each arbitrary primer was mixed with $1 \mu$ l of reverse transcription mix in $1 \times P C R$ reaction buffer (10 $\mathrm{mM}$ Tris $\mathrm{HC} \mathrm{pH} \mathrm{8.3,50} \mathrm{mM} \mathrm{KCl;} 1.5 \mathrm{mM} \mathrm{MgCl}_{2}$ and $0.001 \%(\mathrm{w} / \mathrm{v})$ gelatin and $2 \mu \mathrm{M}$ dNTP in the presence of 0.5 units Amplitaq enzyme (Perkin Elmer), and $0.7 \mathrm{pM}$ of $\alpha\left[{ }^{33} \mathrm{P}\right] \mathrm{dATP}$ (3000 Ci/mmol; New England Nuclear). The total reaction volume was $10 \mu \mathrm{l}$. A drop of mineral oil was added, and the PCR reaction was performed as described below for the labeled primers (1-4).

\section{PCR with labeled primer(s)}

For a single reaction, $4 \mu \mathrm{l}$ of labeled primer mix was added to $8 \mathrm{pM}$ of cold primer and $1 \mu l$ of reverse transcription mix in $1 \times$ PCR reaction buffer (10 mM Tris $\mathrm{HCl} \mathrm{pH} \mathrm{8.3,50} \mathrm{mM} \mathrm{KCl}, 1.5 \mathrm{mM} \mathrm{MgCl}_{2}$, and $0.001 \%$ gelatin) and $2 \mu \mathrm{M}$ or $200 \mu \mathrm{M} d N T P$ in the presence of $0.5 \mu$ AmpliTaq enzyme (Perkin Elmer). The total volume of the reaction was $10 \mu l$. One drop of mineral oil was added, and PCR reaction performed in Perkin Elmer Cetus Thermal Cycler. PCR 
parameters were $94^{\circ} \mathrm{C}$ for $30 \mathrm{sec}, 40^{\circ} \mathrm{C}$ for $2 \mathrm{~min}, 72^{\circ} \mathrm{C}$ for $30 \mathrm{sec}$ with 40 cycles, followed by 5 min elongation at $72^{\circ} \mathrm{C}$.

\section{Primer Labeling}

For a single PCR reaction $10 \mathrm{pM}$ of primer was labeled. The reaction mix with a final volume of $5 \mu \mathrm{l}$ included: $10 \mathrm{pM}$ of oligonucleotide, $6 \mathrm{pM}$ of $\gamma^{32}$ PIATP (3000 Ci/mmol; New England Nuclear) in $1 \times$ kinase buffer (50 mM Tris $\mathrm{Cl} \mathrm{pH}$ 8, $10 \mathrm{mM} \mathrm{MgCl}_{2}, 5 \mathrm{mM}$ DTT, $0.1 \mathrm{mM}$ spermidine, $0.1 \mathrm{mM}$ EDTA) with 2 units of T4 polynucleotide kinase (Promega). Reaction mixture was incubated 45 $\min$ at $37^{\circ} \mathrm{C}$, followed by $5 \mathrm{~min}$ enzyme inactivation at $95^{\circ} \mathrm{C}$.

\section{Gel Electrophoresis of DNA Fragments}

After PCR samples were mixed 5:2 with formamide/dye "stop" solution (United States Biochemical), the mixture was heated at $80^{\circ} \mathrm{C}$ for $2 \mathrm{~min}$ and cooled to $0{ }^{\circ} \mathrm{C} .4 \mu \mathrm{l}$ aliquots were run on standard sequencing $(0.45 \mathrm{~mm}$ thick) denaturing gels (6\% Hydro Link Long-Ranger, 42 g urea per $100 \mathrm{ml}$ gel, 1X Tris borate, $0.05 \%$ ammonium persulfate, $50 \mu 1$ TEMED per $100 \mathrm{~mL}$ gel) on $50 \mathrm{~W}$ for $3.5 \mathrm{~h}$, in $0.6 \mathrm{X}$ Tris borate buffer. 
9353

\section{RESULTS AND DISCUSSION}

Figure 1 documents results comparing the use of labeling with labeled nucleotide incorporation in the PCR reaction with the technique of using a labeled primer (labeled with ${ }^{33} \mathrm{P}$ ). Different quantities of BALB/c thymus total RNA, and polyA+ RNA purified by one passage over an oligo dT cellulose column were amplified with $(\mathrm{T})_{12} \mathrm{MC}$ and either $\mathrm{Rl}$ or Ltk3 arbitrary primer. When labeling was carried out in the PCR reaction, a smear was evident, making bands difficult to discern. Total RNA amplified in a similar way did not show such smearing, suggesting that, as Liang and Pardee (2) conclude, the smearing is from poly dT contamination from the column. This smearing was eliminated when $5^{\prime}$-end labeled primer was used with the same PolyA+ RNA preparation. In those lanes, bands are sharp and defined, with no smearing evident. However, on this sequencing gel, fragments larger than $200 \mathrm{bp}$ were not detected. This is likely due to the low copy number of larger fragments combined with the low energy of ${ }^{33} \mathrm{P}$-labeled primers.

To investigate increasing the sensitivity of the reaction, we changed the labeling source to $\gamma^{32}$ PJATP and raised the concentration of dNTPs from $2 \mu \mathrm{M}$ to $200 \mu \mathrm{M}$. According to Liang and Pardee (1), $2 \mu \mathrm{M}$ concentration of oligonucleotides was: A) necessary for labeling of PCR products by $\alpha\left(S^{35}\right)$ dATP incorporation; B) aiding in the establishment of a higher specificity of PCR amplification of thymidine kinase cDNA with Ltk3 primer. In the conditions 
employed in our experiments, however, labeling was done through using the labeled primers. Therefore, the origin of every band on the display pattern could be attributed to $\left(\mathrm{T}_{12} \mathrm{XY}\right.$, or arbitrary primer, or both. The specificity of $5^{\prime}$ priming in PCR amplification, on the other hand, is preferably to be kept at a level of 6-7 mer for a maximal display of differentially expressed mRNAs.

Figure 2 displays PCR products from reactions in which different labeled primers $\left({ }^{32} \mathrm{P}\right.$-labeled) were employed, arbitrary $\left(\mathrm{R} 1, \mathrm{~S} 5\right.$ and Ltk3) and $(\mathrm{T})_{12} \mathrm{XY}$ $\left[(\mathrm{T})_{12} \mathrm{MC}\right.$ and $\left.(\mathrm{T})_{12} \mathrm{MA}\right]$ primers alternating. It is noteworthy that under the PCR conditions used here, all 3 primers provided similar results with regard to the number of bands, although S5 is a 20 -mer and R1 and Ltk3 are 10-mers. The background smear that can be detected in lanes in which a labeled arbitrary primer and cold $(\mathrm{T})_{12} \mathrm{XY}$ were used can be attributed once again from priming with oligo dT contaminants. In lanes with products of PCR reactions with labeled $(\mathrm{T})_{12} \mathrm{XY}$ and cold arbitrary primers there is significantly less smearing due to successful avoidance of visible products from oligo dT priming. Instead, only some distinct artifactual bands occur in these lanes when compared to their corresponding labeled primer lanes, which is evident in Figs 1 and 2. The bands exclusively detected only in the labeled $(\mathrm{T})_{12} \mathrm{XY} /$ cold arbitrary primer lanes are primed with $(\mathrm{T})_{12} \mathrm{XY}$ from both ends. In the same way, the bands that are exclusively detected only in labeled arbitrary primer lanes are obtained by priming with the arbitrary primer at both ends. Only the bands that occur in both corresponding lanes are likely to 
be the product of $\left(\mathrm{T}_{12} \mathrm{XY}\right.$ priming at $3^{\prime}$ end and the arbitrary primer priming at the $5^{\prime}$ end of the cDNA. It should be noted that corresponding bands are not at identical positions due to the fact that they represent a) coding strand when labeled arbitrary primer is used or b) noncoding strand when labeled $(\mathrm{T})_{12} \mathrm{XY}$ is used. In a label incorporating PCR reaction, on the other hand, both strands are labeled and therefore visible as a doublet. But, even though only one strand of a particular fragment will be displayed with labeled primer use, some fragments will still be doubled due to an additional incorporation of $A$ residues at the $3^{\prime}$ ends by Taq polymerase (4).

Our results demonstrate that the use of labeled $(\mathrm{T})_{12} \mathrm{XY}$ primers for differential display of eukaryotic PolyA+ RNA preparations permits better resolution and finer detail of bands when poly oligo dT tracts contaminate the RNA preparation. These oligo dT tracts, a contaminant of oligo dT column chromatography, serve as random primers, and in a PCR labeling reaction create size-varying products which are detected as a smear on a sequencing gel. When only a diagnostic screening is needed, one can use only labeled (T) ${ }_{12} \mathrm{XX}$ primers for differential display. When, on the other hand, cloning of differentially expressed bands is to be pursued, both $5^{\prime}$ and $3^{\prime}$ primers should be as labeled and run side-by-side on the same gel. The use of different/complementary 5'-kinase-labeled primers allows for detection of the origin of the certain band(s) evident on sequencing gel after PCR reaction. This will allow for discerning only the correctly primed PCR products, with $(\mathrm{T})_{12} \mathrm{XY}$ 
priming on $3^{\prime}$ end and arbitrary priming on $5^{\prime}$ end of the synthesized PCR product. All the other bands, primed by $(\mathrm{T})_{12} \mathrm{XY}$ or arbitrary primer from both ends will be avoided. 


\section{ACKNOWLEDGEMENTS}

The authors wish to thank Dr. Cheryl Denault for initially introducing differential display technology into the laboratory, Ms. Chi-Mei Chang-Liu for making RNA samples available, Ms. Kay Bexson for excellent secretarial assistance, and Drs. Radoje Drmanac and Jeff Schwartz for review of this manuscript. Work supported by the U.S. Department of Energy, Office of Health and Environmental Research, under Contract No. W-31-109-ENG-38. Address correspondence to G.E. Woloschak. 


\section{REFERENCES}

1. Liang,P. and Pardee,A.B. (1992) Science, 257, 969-971.

2. Liang,P., Averboukh,L. and Pardee,A.B. (1993) Nucl. Acids Res., 21, 3269-3275.

3. Liang,P., Averboukh,L., Keyomarsi,K., Sager,R. and Pardee,A.B. (1992) Cancer Res., 52, 6966-6968.

4. Bauer,D., Müller,H., Reich,J., Riedel,H., Ahrenkiel,V., Warthoe,P. and Strauss,M. (1993) Nucl Acids Res., 21, $4272-4280$.

5. Caetano-Anolles,G., Bassam, B.J. and Gresshoff,P.M. (1991) Biotechnology, 9, 553-556.

6. Welsh,J. and McClelland,M. (1990) Nucl Acids Res., 18, 7213-7218.

7. Welsh,J., Chandra,K., Dalal,S., Cheng,R., Ralph,D. and McClelland,M. (1992) Nucl. Acids Res., 20, 4965-4970.

8. Shultz,L.D, Sweet,H.O., Davisson,M.T. and Conan,D.R. (1982) Nature, 297, 402-404.

9. Woloschak,G.E., Rodriguez,M. and Krco,C.J. (1987) J. Immunol, 138, 2493-2499.

10. Woloschak,G.E, Liu,C-M., Jones,P.S. and Jones,C.A. (1990) Cancer Res., 50, 339-344.

11. Woloschak,G.E., Krco,C.J. and Rodriguez,M. (1988) Regional Immunology, 1, 163-171. 
12. Lai,C-C., Chiu,T.H., Rosenberg,H.C. and Huang,W-H. (1993) Biotechniques, 15, 620-626. 
Figure 1. Figure 1 is an autoradiogram of a sequencing gel used for differential display using ${ }^{33} \mathrm{P}$-labeled primers or ${ }^{33} \mathrm{P}$-dATP incorporation in the reaction mix. Below is a matrix describing the contents of each lane. The number in the matrix is the lane number for Fig. 1. Based on the matrix, the reaction for lane 1 used $0.1 \mu \mathrm{g}$ of input RNA, reverse transcribed then PCR-labeled with ${ }^{33} \mathrm{P}$-dATP in the reaction mix, using (T) 12MC and Ltk3 as the PCR-primers; the reaction for lane 2 used $0.1 \mu \mathrm{g}$ of input RNA, reverse transcribed, then amplified with cold Ltk3 and ${ }^{33} \mathrm{P}$-labeled $(\mathrm{T})_{12} \mathrm{MC}$; etc.

\begin{tabular}{|c|c|c|c|c|c|c|c|}
\hline \multicolumn{2}{|c|}{ Cold primer(s) } & $(\mathrm{T})_{12} \mathrm{MC} ;$ Ltk3 & Ltk3 & $(\mathrm{T})_{12} \mathrm{MC}$ & $(\mathrm{T})_{12} \mathrm{MC} ; \mathrm{R} 1$ & RI & $(\mathrm{T})_{12} \mathrm{MC}$ \\
\hline \multicolumn{2}{|c|}{ Source of label } & $\begin{array}{l}\alpha\left[{ }^{33}\right] \mathrm{dATP} \\
\text { incorporation }\end{array}$ & $\begin{array}{l}\text { (T) }{ }_{12} \mathrm{MC} \\
5^{\prime} \gamma^{33} \mathrm{Pl} \\
\end{array}$ & $\begin{array}{l}\text { Ltk3 } \\
5^{\prime} y^{33} \mathrm{Pl}\end{array}$ & $\begin{array}{l}\alpha\left[{ }^{33 \mathrm{P}}\right] \mathrm{dATP} \\
\text { incorporation }\end{array}$ & $\begin{array}{l}\text { (T) }{ }_{12} \mathrm{MC} \\
5^{\prime} \gamma^{33} \mathrm{Pl}\end{array}$ & $\left.5^{\mathrm{R} 1} \hat{\gamma}^{33} \mathrm{P}\right]$ \\
\hline \multicolumn{8}{|c|}{ Template: } \\
\hline \multirow{2}{*}{$\begin{array}{l}\text { Total } \\
\text { RNA }\end{array}$} & $0.2 \mu g$ & 4 & 5 & 6 & 19 & 20 & 21 \\
\hline & $0.02 \mu \mathrm{g}$ & & & & 16 & 17 & 18 \\
\hline \multirow{3}{*}{ mRNA } & $0.2 \mu g$ & & & & 13 & 14 & 15 \\
\hline & $0.1 \mu \mathrm{g}$ & 1 & 2 & 3 & 10 & 11 & 12 \\
\hline & $0.01 \mu \mathrm{g}$ & & & & 7 & 8 & 9 \\
\hline
\end{tabular}


T. Paunesku

Figure 2. Figure 2 is an autoradiogram of a sequencing gel used for differential displa The number in the matrix is the lane number for Fig. 2. Based on the matrix, the rea PCR-amplified with ${ }^{32} \mathrm{P}$-labeled $\mathrm{R}_{1}$ and cold $(\mathrm{T})_{12} \mathrm{MC}$ as the primers; lane 2 used $0.2 \mu$ labeled $(T)_{12} \mathrm{MC}$ and cold $\mathrm{R}_{1}$; etc.

\begin{tabular}{|c|c|c|c|c|c|}
\hline Cold primer & $(\mathrm{T})_{12} \mathrm{MC}$ & R1 & $(\mathrm{T})_{12} \mathrm{MA}$ & $\mathbf{R} \mathbf{1}$ & $(\mathrm{T})_{12} \mathrm{MC}$ \\
\hline $\begin{array}{l}\text { Labeled primer } 5^{\prime} \\
y^{32} \mathrm{Pl}\end{array}$ & RI & $(\mathrm{T})_{12} \mathrm{MC}$ & Rl & $(\mathrm{T})_{12} \mathrm{MA}$ & Ltk3 \\
\hline $\begin{array}{l}\text { total RNA } 0.2 \mu \mathrm{g} \\
\text { thymus } \mathrm{BCF}_{1}\end{array}$ & 1 & 2 & & & 11 \\
\hline $\begin{array}{l}\text { mRNA } 0.2 \mu g \\
\text { thymus BCF } \\
\end{array}$ & 3 & 4 & & & 13 \\
\hline $\begin{array}{l}\text { mRNA } 0.2 \mu g \\
\text { liver } \mathrm{BCF}_{1}\end{array}$ & & & 5 & 6 & \\
\hline $\begin{array}{l}\text { mRNA } 0.2 \mu g \\
\text { liver wst/wst }\end{array}$ & & & 7 & 8 & \\
\hline $\begin{array}{l}\text { mRNA } 0.2 \mu \mathrm{g} \\
\text { liver wst/. }\end{array}$ & & & 9 & 10 & \\
\hline
\end{tabular}


y using ${ }^{32} \mathrm{P}$-labeled primers. Below is a matrix describing the contents of each lane. ction for lane 1 used $0.2 \mu$ g total RNA from $\mathrm{BCF}_{1}$ thymus, reverse transcribed then $g$ total RNA from $\mathrm{BCF}_{1}$ thymus, reverse transcribed then $\mathrm{PCR}$-amplified with ${ }^{32} \mathrm{P}$ -

\begin{tabular}{l|l|l|l|l|l|l}
\hline Ltk3 & $(\mathrm{T})_{12} \mathrm{MA}$ & Ltk3 & $(\mathrm{T})_{12} \mathrm{MC}$ & $\mathrm{S5}$ & $(\mathrm{T})_{12} \mathrm{MA}$ & $\mathrm{S5}$ \\
\hline$(\mathrm{T})_{12} \mathrm{MC}$ & Ltk3 & $(\mathrm{T})_{12} \mathrm{MA}$ & $\mathrm{S5}$ & $(\mathrm{T})_{12} \mathrm{MC}$ & $\mathrm{S5}$ & $\left(\mathrm{T}_{12} \mathrm{MA}\right.$ \\
\hline 12 & & & 21 & 22 & & \\
\hline 14 & & & 23 & 24 & & \\
\hline & 15 & 16 & & & 25 & 26 \\
\hline & 17 & 18 & & & 27 & 28 \\
\hline
\end{tabular}




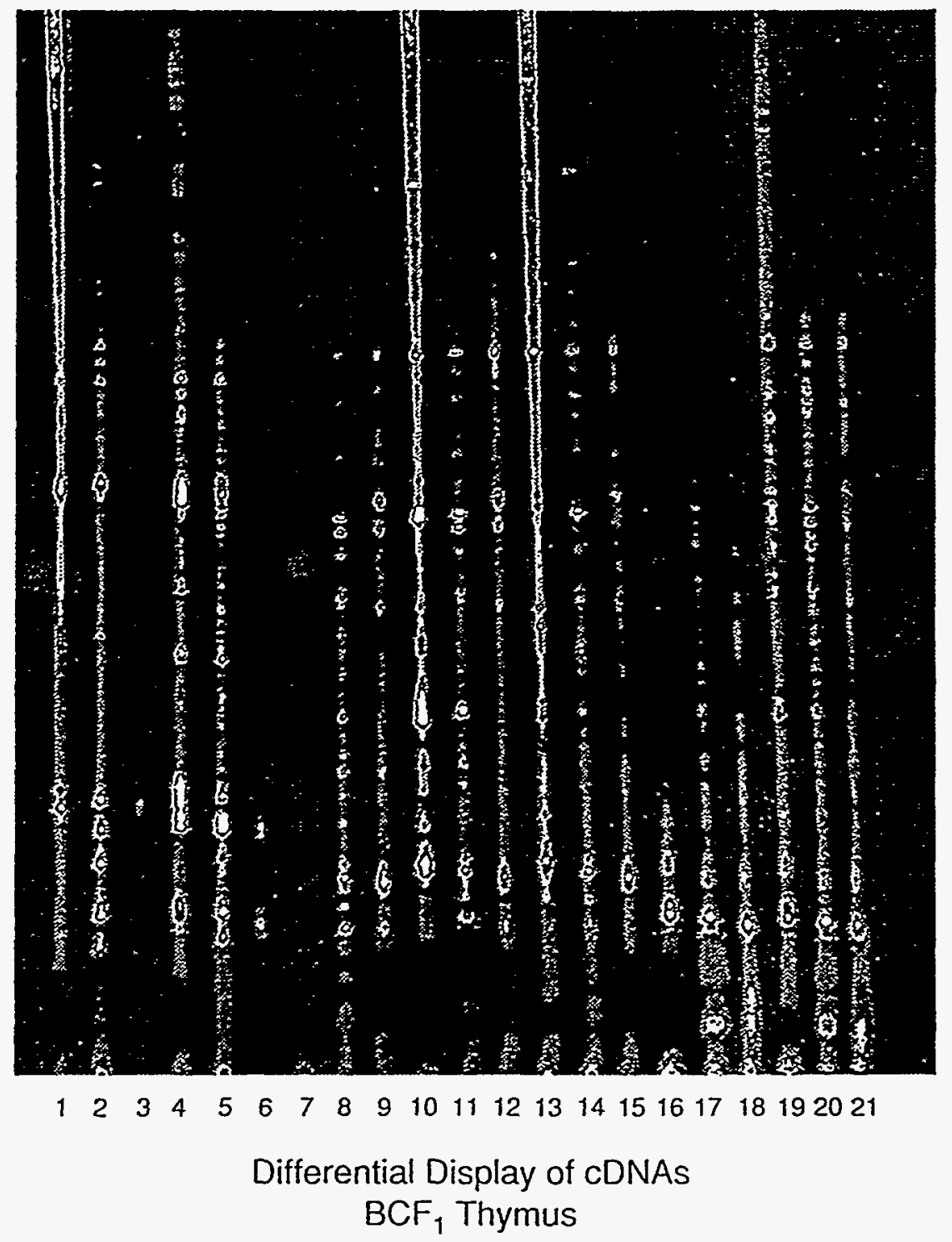

Fi: 
